\title{
Lecturers' Perception of Intellectual Property Rights in Universities in Rivers State
}

\author{
C. Amini Philips (Corresponding author) \\ Department of Educational Management, Faculty of Education \\ University of Port Harcourt, Nigeria \\ E-mail: drchiap22@gmail.com \\ Cecilia Ibiene Chinda \\ Department of Educational Management, Faculty of Education \\ University of Port Harcourt, Nigeria
}

Received: February 02, 2017 Accepted: February 28, 2017 Published: March 11, 2017

doi:10.5296/ijhrs.v7i1.10903 URL: http://dx.doi.org/10.5296/ijhrs.v7i1.10903

\begin{abstract}
This study investigated lecturers' perception of intellectual property rights in universities in Rivers State. The research design for the work was descriptive survey. The population of the study was 2,551 lecturers in the three universities in the state. The sample used for this study was 346 university lecturers which represents $13.6 \%$ of the population arrived at using the Taro Yamen formula. Data was collected by formulating and administering structured questionnaire titled 'Lecturers perception of Intellectual Property Right Questionnaire' (LPIPRQ). The instrument was dully validated and reliability yielded 0.85 using test-retest method and calculated with Pearson's Product Moment Correlation Coefficient (PPMCC) formula. Mean scores, standard deviation and rank order statistics were applied to derive answers to the research questions and z-test was applied to test the null hypotheses at 0.05 level of significance. The study revealed a number of findings; that University lecturers have a high perception of intellectual property, including the rights of intellectual property. The results necessitated the recommendation that, intellectual property unit should be established and strengthened in universities to screen all intellectual write-ups before publication. Government should provide special fund to universities for the procurement of ICT facilities for the enhancement of the rights of lecturers to intellectual property.
\end{abstract}

Keywords: Student' performance, Professional competency, Higher education 


\section{MInstitute ${ }_{\text {Mnk }}^{\text {Macrothink }}$}

\section{Introduction}

Humankind is known to have an innate creative faculty through which he conceives designs and produces aesthetics works of arts. Such works are known as intellectual property (IP), owned by the original inventors. Intellectual property refers to creations of the mind. It includes music, literature and other artistic works, discoveries, words, etc. (Branstetter, Fisman and Foley, 2006). Although such inventions are fashioned to facilitate other development of knowledge, specialized disciplines and society at large, they also provide opportunities for livelihood for the originators of such inventions.

The design and development of IP often involve expenditure which owners from an economic standpoint may view as investment expenditure. They anticipate making and perhaps maximizing the returns of such inventions from proceeds made from such inventions. A cardinal goal of research is commercialization of research findings which directly leads to the improvement of society. Given that intellectual properties are designed, financed and produced by the originators, the right of IP laws has been made to ensure that the originators are granted rights that are exclusive to the ownership and profits of their inventions. This means that they are legally the originators of their inventions and have the right (exclusive) to reproduce and commercialize it. It is therefore illegal for anyone to be engaged in claiming ownership, reproducing or commercializing another person's intellectual property without his permission and consent. In an effort to provide justification for the introduction of IP right, Mendis, Sechi and Reevis (2015) argued that if the inventions of scientists, researchers, writers, and authorities are not protected from piracy, the original inventors would die in penury while those who pirate their works will get rich. The management of the right of IP involves the process of creating awareness of IP right and the measures for its management and also ensuring lecturers' compliance. Academic staff perception of IP is critical to determining the degree of success that would be recorded in the quest to effectively manage the IP right in the universities in the state.

\subsection{Aim and Objectives of the Study}

The study's cardinal aim was to look into lecturers' perception of IP rights in universities located in Rivers State. Specifically, the objectives of the research are:

To establish the perception level of lecturers on what constitutes the IP in the universities located in Rivers State.

To determine the perception level of lecturers on what constitutes rights of IP in the universities situated in Rivers State

\subsection{Research Questions}

What is the perception level of lecturers on what constitutes IP in the universities situated in the state?

What is lecturers' perception level on what constitutes IP rights in the universities located in the state? 


\subsection{Hypotheses}

The work was guided by the hypotheses below which were tested at 0.05 level of significance:

Ho: No significant difference exists between the mean perception scores of both gender lecturers' perception level on what constitutes IP in the universities situated in the state.

Ho2: There is no significant difference in Professors and Non Professors perception mean scores on what the rights of IP in the universities located in the state.

\section{Theoretical Framework}

The labour theory of property propounded by John Locke (1692) was reviewed and used as theoretical framework for this study. This theory is also known as 'labour theory' or 'appropriation and labour theory of entitlement'. This theory gives a theoretical support to the IP right development. In the theory, Locke explains that a person who carries out an act of original appropriation of natural resources should have permanent ownership of such natural resources. From a theoretical standpoint therefore, if a person is able to transform natural resources/ raw materials (which include facts, concepts and ideas) that are held in common into processed products of enhanced values, the State has a duty to enforce natural rights that ensures that the person derives the natural right that is derivable from such labour.

The idea of property for Locke is that property originally comes about by the exertion of labour into the process of transforming raw materials into processed products. In the case of intellectual property, intellectual labour is the labour which a person has to exert in the development of creations of the mind in order for the person to be entitled to having a right of ownership. The process of production of mind creation is seen as an economic investment venture that must have the State's protection since such investments would also contribute to the State's development. The protection of the right of property is to ensure that property owners continue to get the benefits of their labour input.

There have been concerns over how the difference between common property and personal property can be made. Locke's explanation is that common property often lacks aesthetics of usefulness qualities that will enable them to be commercialized. He posited that a labour input is necessary for transforming a common property into a commodity that with utility value-the benefit which a person who has made a labour input into the creation of products with commercial utility-value is that he should have the right of personal property.

It is Locke's explanation that if nothing is done by the State to ensure separation of personal property (owned by producer) from common property (that are the gifts of nature to the State) including its protection of the people who have the ownership of personal property, the State will decrease in the development and growth rate - this is because there will be gross decrease, in the amount of personal property produced in the State. Locke saw the protection property right as an encouragement which those who invest their labour in creation of such properties would enjoy from the State. Locke's property right theory provided a framework for the advancement of State's intellectual property right protection. 
This theory is relevant to the study in the sense that it provides a logical insight into the relationship between personal property right (i.e. IP right and people's attitude towards creation of personal property. Sequel to Locke's explanation, people's perception of IP management by State or relevant agencies like the university authorities will affect their attitude and commitment towards IP production. In line with this theoretical position, the researchers' therefore examined academic staff perception of the rights of IP in universities.

Going by Locke's theory, it is the State's responsibility to ensure the property protection right of individuals. Sequels to this, the university authorities are viewed to be responsible for the IP right management within the university community. The academic staff members who are perhaps engaged in the IP production therefore would expect that the university authorities make the right arrangement for the management of their personal property right. This explanation therefore provides a relevant framework for the researchers' choice of examining academic staff perception of IP and the right of IP in the universities located in the State.

\subsection{Concept of Intellectual Property}

IP refers to any creation or invention of the minds of humans. Such creations are basically ideas conceived, harnessed, designed and developed through human intellectual activity. Characteristically, intellectual properties possess qualities of ingenuity and novelty. Several definitions of intellectual property exist. Branstetter, Fisman and Foley (2006) pointed out that IP refers to creations of the human mind and includes inventions such as literary and artistic works, designs and symbols, images and names used in trade or commerce.

Intellectual property therefore is a product of the cognitive domain of humans - it involves the activities of the human brain to identify or create sounds, symbols and art designs that conveys useful concepts, ideas or messages. Intellectual property is linked with a branch of philosophy which stresses the study of the origin and usefulness of aesthetics, beauty or values of artistic works. Axiology is this branch of philosophy. Intellectual property therefore covers all shapes of human intellectual inventions that create an appeal to aesthetic considerations of the target users or consumers. Some of the aesthetic products considered as IP include artistic works of music, dance, symbols, words, articles, etc.

To ensure that IP is easily accessed and used by the target consumers, some are usually harnessed and packaged in form of print contents in publications as books, journals, thesis, articles, etc. Others are in the form of electronic content in audio and audio-visuals stored in Compact Disk (CDs), jingles and radio or TV shows. Some IPs that are accessible online through the aid of the internet exist. There are still some that are stored in the form of paintings, drawing, graphics, etc. Without harnessing and storing intellectual creations, it will be almost impossible for any individual or organization to lay claim of the ownership or originator of such intellectual inventions (McCalman, 2005).

Intellectual property plays significant roles in the advancement of society. They are a dependable root of novel information and knowledge - they can therefore be used as vehicles for education, transmission of values including tackling emerging social problems through orientation and re-orientation. Music and drama for instance were found useful in Rome and 


\section{Ml Macrothink}

International Journal of Human Resource Studies

ISSN 2162-3058

2017, Vol. 7, No. 1

Greek for education and building of values. Intellectual property can also help to foster development and economic growth because such aesthetic products do have intrinsic and extrinsic economic values. It provides a source of livelihood for the originators or authors including middlemen who may be licensed or authorized to commercialize such products

Since universities are saddled with the task of teaching, research and commercialization of research findings, intellectual property play significant roles in the achievement of the goals of universities. Lecturers, researchers and students are required to create IP that will enhance delivery and students and lecturers performance. Such intellectual property includes research works, journals, books, articles, etc. Apart from enhancing service delivery and performance of university personnel, development of intellectual property also provides opportunities for economic survival for both the universities and the originators/authors.

Given the wide spread recognition of the contributions of IP to societal development and enhancement of service delivery in universities, there is a growing agitation for stakeholders and the government to create an enabling environment that will encourage high rate of creation of IP. One of such enabling environment that is highly sought after both locally and international is the enactment and execution of the right of IPs (Africa-Europe Faith \& Justice Network, 2002).

University is a large and complex system - basically it has several faculties and departments. The implication of the above is that what constitutes IP in universities may differ from one faculty to another. It is common to observe that lecturers in science may consider IP to include scientific inventions like machines; scientific theories, laws, symbols and formulas; etc. Those in humanities might consider it to include music, paintings, drawings, pictures, fashion styles, colourings, carved images, etc. for learners in the social sciences would consider IP to include, theories, laws, print and electronic publications, etc.

\subsection{The Right of Intellectual Property, how it is perceived and its Constituents in Universities}

To protect the IP of authors, certain IP right laws have been enacted. Several views of IP right exist. Maskus and Penubari (1995, p.227) explained that, "Intellectual Property Right (IPR) are rights given to a person or a company by a state for products of intellectual effort and ingenuity. Forms of IPR include: patents, copyright, trademark, labels or plant traders right". The World Intellectual Property Organization (WIPO) was established in 1967. Article 2 Section viii of the convention establishing this has it that intellectual property shall include right relating to:

- Scientific, artistic and literary works

- Performances of artists that are performing, phonograms and broadcasts

- Inventions in all disciplines

- Scientific discoveries

- Industrial designs

- Trademarks, services marks, designations and commercial names 
- Protection against unwholesome competition, including all other rights resulting from intellectual activity in the scientific, literary, industrial or artistic fields.

According to University of Port Harcourt, Intellectual property Policy (2013, p8), IPRs are as follows:

- Patent: Right granted for an invention, innovations or discoveries.

- Trademark: Right given/granted to a person for distinctive goods produced or services provided.

- Copyright: Right given to authors for their creative work e.g. literacy works computer programmes, data base film, musical compositions, choreography, artworks, architectural designs and technical drawings.

- Breeder's Right: Right given to a breeder for research efforts in the production of crops, animal health, livestock, fisheries, forestry and the storage of crops.

IPRs are aimed at ensuring that IP owners continue to enjoy right to ownership of the property and control of its commercial benefits. Most inventors of IP invest lots of time and other resource in designing and inventing of IP which is also intended to be commercialized IP is in itself a form of investment (Rapp \& Rozek, 1990). The enactment of IPR provides a legal framework for prosecuting anyone whose actions portends a claim of the ownership of another person's IP or an act of making, commercializing and making economic proceeds from an IP that belongs legally to someone else.

Sequel to the enactment of IPR, it is a crime for anyone to violate such right. Offenders therefore are prosecuted by the provisions of the laws and sanctions governing the protection of IPR. The rationale for the enactment of IPR is to:

- Stimulate growth in the stock of IP, generated in an industry and society

- Stimulate ingenuity and novelty in IP creation.

- According to Mendis, Sech and Reevis (2015), if the inventions of scientists, scholars, researchers and writers are not protected from piracy, the original inventors would die in penury while those who pirate their works will get rich. Thus, IPRs are necessary for ensuring that inventors of IP are not mugged of their economic returns.

- To foster internationalization of IP. Nagasoka (2002) stated that the mission of WIPO (an international advocate of IPR ) is to promote through international cooperation the creation, dissemination, protection of works and use of the minds of humans for the social, economic and cultural progress of all mankind.

Universities in Nigeria have consistently shown immense support for IPR protection of personnel. The origination of IP in universities is one of the requirements for career growth amongst lecturers thus, every lecturer is required by the universities to publish articles in journals of great reputes, present papers, publish books and other related works. Apart from providing a prospect for career growth, intellectual property also provides opportunity for 
lecturers to make proceeds from the commercialization of these works. Given that some lecturers and miscreants may wish to lay claim on the works of other lecturers or even commercialize and make proceeds from the IP of others, the protection of IP is of interest amongst lecturers.

The certainty or uncertainty of proper awareness of IPR in universities has gained the interest of lecturers. This is as a result of the high desire of lecturers to have their IP safeguarded against piracy, plagiarism or patent. Although the lack of knowledge of the law has been described as no excuse at the face of justice, it is noteworthy to mention that lack of knowledge of the law would make the violation of the law inevitable. The necessity of the awareness of IPR amongst lecturers cannot be overemphasized.

Sensitization and orientation has remained a major reliable way of combating all manners of crime. Africa-Europe Faith \& Justice Network (2002) argued that the war against piracy, plagiarism and patent can be won through continuous sensitization of the general public. The essence of such sensitization is to educate the public about the consequences and cost of IP violation both to the originators of such property and to the economy at large. Furthermore, it is to mobilize everyone to shun any form of patronage of pirated and plagiarized materials thus protecting the return on investment of the originators of the IP.

University authorities and relevant agencies therefore also need to continuously sensitize lecturers on the consequences of violating the right of property on victims and also on the culprits. Newly recruited lecturers and serving lecturers need periodic workshops on IPR this is necessary because all lecturers are required by the universities to author and produce intellectual property. The tendency has always being that some lecturers find it convenient to plagiarize the books and publications of other perhaps hardworking lecturers.

Again since there is a quest for internationalization and globalization of university education, there is a global concern of repeated cases of lecturers pirating or plagiarizing the works of authors from other foreign universities. This concern has perhaps resulted in the efforts towards subjecting publications to several forms of plagiarism and piracy tests before they are allowed to be published in foreign journals or websites. Given the high rate of plagiarism, there are arguments over the certainty of adequate effort towards increasing the awareness of IPR and the result of such rights violation.

The effort towards fostering lecturers' awareness of IPR is expected to amongst others aim at ensuring that lecturers are:

- Abreast of these IP laws enacted globally, domestically and at the university level.

- Abreast of the legal implications of any IPR violation - i.e., the sanctions and penalties that will be meted out on culprits.

- Aware of the several acts that could be termed violation of IPR.

- Aware of the provisions (legal) for seeking justice when their IPR are being violated. When lecturers seek justice and justice is eventually done, it will 
serve as deterrent to others.

- Possess the right perception and attitude towards intellectual property right.

The fact that laws usually create tension makes it worthwhile to take into consideration how lecturers perceive IPR. People's perception of IPR will affect their attitude and degree of compliance. If lecturers perceive IPR as worthwhile, and one that must be respected and protected by all and sundry, they will show positive attitude and compliance towards it. According to Peremotode (2009), the strengths of laws are the sanctions attached to it.

This implies that people's attitude and compliance to any law will be determined by how they perceive the sanctions. Another critical factor that may affect how lecturers see IPR is how they view the university IPR arrangement.

\subsection{Empirical Reviews}

In an empirical study, Nicholson (2002) examined intellectual property and internalization. The design of the study was co-relational survey. The research questions asked were four. The study population was 2,551officials, while the sample was 46 respondents which represented $10 \%$ of the population. Simple random sampling technique was utilized. The instrument for the collection of data was an adapted questionnaire that was duly validated by the research supervisor and other lecturers. The research questions were answered using weighted mean and percentages. The study revealed that the effective management of intellectual property right would lead to an increase in the growth of intellectual property creation.

This empirical review is relevant to this study because it provides empirical evidence of the significance of a study of intellectual property rights perception. Also it provides insight on the limitations of empirical examination of intellectual property rights management issues. Gaps which exist in the study under empirical review provided a rationale for the conduct of this study. These gaps include; failure to examine the academic staff perception of the intellectual property and rights in universities.

Another empirical study was conducted by McCalman (2005). The aim of the study was to examine international diffusion and intellectual property right. Weighted mean and standard deviation were used to answer the five questions that were raised to guide the study. The sampling technique used in selecting the sample was simple random sampling technique. The empirical study reviewed revealed that intellectual property rights affects international diffusion of intellectual property and that the management of intellectual property rights will help the creation and international diffusion of original creations of the mind. The empirical study reviewed is relevant to this study because it shows the issue of intellectual property rights has gained the attention of researchers and it also provides insight into what areas that have been researched and the gaps that require further research.

The gaps which are identified in the empirical study reviewed is that the study failed to examine how perhaps a group of stakeholders (like university lecturers) perceive intellectual property right. 


\section{Methodology}

The research design for this study was descriptive survey. This design was considered appropriate because a descriptive survey design has to do with the use of a selected sample for that study that will lead to generalization of the findings over the entire population of the study. Furthermore, it is concerned mostly with the provision of a vivid description of the various variables that make-up a phenomenon that is being investigated.

The population of the study was all the three universities in Rivers State (federal and state). There are 2,551 lecturers in these Universities. This included 1,420 male lecturers and 1,131 female lecturers (Source: University Academic Planning Reports, 2015).

The sample used for this study was 346 university lecturers. This sample was derived using Taro Yamane formula. The proportionate stratified random sampling technique was used to select the sample from the population, and this represented $13.6 \%$ of the population. The sample was drawn from University of Port Harcourt (UNIPORT), Rivers State University of Science and Technology (RSUST) and Ignatius Ajuru University of Education (IAUOE) all in Rivers State; and examined lecturers perception based on their gender and status. The composition includes; 200 male and 146 female lecturers; and 76 Professors and 270 Non Professors.

The instrument used for data collection in this study was a questionnaire titled 'Lecturers perception of Intellectual Property Rights Perception Questionnaire' (LPIPRQ). It is an adapted 4-point Likert scale questionnaire that was designed by the researchers. The questionnaire had two sections. Section A was used to collect the personal data of respondents such as gender and status, while Section B was used to collect required data based on the research variables.

An adapted four-point Likert rating scale was used to determine the mean criterion that was used in answering the research questions. The adapted four point's ratings included;
$\mathrm{H}=$ High
$=4$ point,
$\mathrm{M}=$ Moderate $\quad=3$ point,
$\mathrm{L}=$ Low $=2$ point,
$\mathrm{VL}=$ Very Low $=1$ point.
$\mathrm{SA}=$ Strongly Agree $=4$ point,
$\mathrm{A}=$ Agree $\quad=3$ point,
$\mathrm{D}=$ Disagree $\quad=2$ point,
$\mathrm{SD}=$ Strongly Disagree $=1$ point. 


\section{Macrothink

The criterion mean for this study was calculated as;

$\frac{4+3+2+1}{4}=\frac{10}{4}=2.50$

Mean scores, standard deviation and rank order statistics were used to answer the research questions. The criterion mean (2.50) was used as criterion for making decisions whether or not a questionnaire item was agreed or disagreed. In the event that the mean score rating of a particular questionnaire item was 2.50 or above 2.50 , that item was agreed but in the event that the mean score rating was less than 2.50 , the questionnaire item was disagreed.

Z-test was used to test the null hypotheses. When the z-calculated value is equal to or greater than the critical value of \pm 1.96 , the hypothesis was rejected. But when the Z-calculated was less than the critical value, the hypothesis was accepted. 


\section{Macrothink \\ International Journal of Human Resource Studies \\ ISSN 2162-3058 2017, Vol. 7, No. 1}

\section{Data Analysis}

\subsection{Research Question One}

What is the level of perception of lecturers on what constitutes intellectual property in universities in Rivers State?

Table 1: Mean scores and standard deviation on the level of perception of lecturers on what constitutes intellectual property in Universities in Rivers State.

\begin{tabular}{|c|c|c|c|c|c|c|c|c|}
\hline \multirow[t]{2}{*}{ S/No } & \multirow[t]{2}{*}{$\begin{array}{l}\text { Constituents of intellectual } \\
\text { property in universities } \\
\text { include: }\end{array}$} & \multicolumn{2}{|c|}{$\begin{array}{c}\text { MALE } \\
\text { LECTURERS } \\
\mathbf{N}=\mathbf{2 0 0} \\
\end{array}$} & \multicolumn{2}{|c|}{$\begin{array}{c}\text { FEMALE } \\
\text { LECTURERS } \\
\text { N=146 } \\
\end{array}$} & \multirow[t]{2}{*}{$\begin{array}{l}\text { MEAN } \\
\text { SET }\end{array}$} & \multirow[t]{2}{*}{$\begin{array}{l}\text { Rank } \\
\text { order }\end{array}$} & \multirow[t]{2}{*}{ DECISION } \\
\hline & & $\bar{X}$ & SD & $\bar{X}$ & SD & & & \\
\hline 1. & $\begin{array}{l}\text { Published print and electronic } \\
\text { books, journals and articles }\end{array}$ & 2.97 & 0.50 & 3.04 & 0.58 & 3.01 & $4^{\text {th }}$ & $\begin{array}{l}\text { Agree } \\
\text { High }\end{array}$ \\
\hline 2. & $\begin{array}{l}\text { Developed theories, laws and } \\
\text { mathematical formula and } \\
\text { symbols }\end{array}$ & 3.05 & 0.49 & 3.13 & 0.57 & 3.09 & $1^{\text {st }}$ & $\begin{array}{l}\text { Agree } \\
\text { High }\end{array}$ \\
\hline 3. & $\begin{array}{l}\text { Scientific research discoveries and } \\
\text { inventions }\end{array}$ & 3.17 & 0.48 & 2.86 & 0.59 & 3.02 & $3^{\text {rd }}$ & $\begin{array}{l}\text { Agree } \\
\text { High }\end{array}$ \\
\hline 4. & Statistical data and reports & 3.05 & 0.49 & 2.86 & 0.59 & 2.96 & $5^{\text {th }}$ & $\begin{array}{l}\text { Agree/ } \\
\text { Moderate }\end{array}$ \\
\hline 5. & Paintings and drawing of art & 3.12 & 0.49 & 3.00 & 0.58 & 3.06 & $2^{\text {nd }}$ & $\begin{array}{l}\text { Agree } \\
\text { High }\end{array}$ \\
\hline & Aggregate Mean & 3.07 & 0.49 & 2.98 & 0.58 & 3.03 & & High \\
\hline
\end{tabular}

Scale: High $=3.0-4.0$, Moderate $=2.50-2.99$, Low $=1.0-2.49 ;$ and Very low $=0.01-0.99$

The respondents, both male and female lecturers accepted all the items in the table as intellectual property in Universities with mean scores greater than the criterion mean of 2.50. The aggregate mean score of 3.07 with the standard deviation of 0.49 for male and 2.98 with standard deviation of 0.58 for females showed that the level of perception for male is high while that of female lecturers is moderate. Therefore, intellectual property in universities include: published print and electronic books, journals and articles, developed theories, laws and mathematical formula and symbols, scientific research discoveries and inventions, statistical data and reports, painting and drawing of arts. Furthermore, developed theories, laws and mathematical formula and symbols was ranked $1^{\text {st }}$, painting and drawing of arts was ranked $2^{\text {nd }}$, scientific research discoveries and inventions was ranked $3^{\text {rd }}$, published print, electronic books, journals and articles was ranked $4^{\text {th }}$, while statistical data and report was ranked $5^{\text {th }}$. 


\subsection{Research Question Two}

What is the level of perception of lecturers on what constitutes intellectual property right in universities in Rivers State?

Table 2: Level of perception of lecturers' on what constitutes intellectual property right in universities in Rivers State

\begin{tabular}{|c|c|c|c|c|c|c|c|c|}
\hline \multirow[t]{2}{*}{ S/No } & \multirow[t]{2}{*}{$\begin{array}{l}\text { Constituents of intellectual } \\
\text { property right in } \\
\text { universities include: }\end{array}$} & \multicolumn{2}{|c|}{$\begin{array}{c}\text { PROFESSOR } \\
\text { LECTURERS } \\
\quad \mathbf{N}=76\end{array}$} & \multicolumn{2}{|c|}{$\begin{array}{c}\text { NON PROF } \\
\text { LECTURERS } \\
\mathbf{N}=\mathbf{2 7 0} \\
\end{array}$} & \multirow[t]{2}{*}{$\begin{array}{l}\text { MEAN } \\
\text { SET }\end{array}$} & \multirow[t]{2}{*}{$\begin{array}{l}\text { Rank } \\
\text { order }\end{array}$} & \multirow[t]{2}{*}{ DECISION } \\
\hline & & $\bar{X}$ & SD & $\bar{X}$ & SD & & & \\
\hline \multirow[t]{2}{*}{6} & Patent & 3.13 & 0.79 & 3.02 & 0.42 & 3.08 & $4^{\text {th }}$ & Agree \\
\hline & & & & & & & & High \\
\hline 7 & Trademark & 3.03 & 0.80 & 3.14 & 0.42 & 3.09 & $3^{\text {rd }}$ & $\begin{array}{l}\text { Agree } \\
\text { High }\end{array}$ \\
\hline 8 & Breeder's right & 3.15 & 0.79 & 2.82 & 0.44 & 2.99 & $5^{\text {th }}$ & $\begin{array}{l}\text { Agree } \\
\text { High }\end{array}$ \\
\hline 9 & Copyright & 3.02 & 0.80 & 3.21 & 0.41 & 3.12 & $1^{\text {st }}$ & $\begin{array}{l}\text { Agree } \\
\text { High }\end{array}$ \\
\hline \multirow[t]{2}{*}{10} & Industrial design right & 3.13 & 0.79 & 3.08 & 0.42 & 3.11 & $2^{\text {nd }}$ & $\begin{array}{l}\text { Agree } \\
\text { High }\end{array}$ \\
\hline & Aggregate Mean & 3.09 & 0.79 & 3.05 & 0.42 & 3.08 & & High \\
\hline
\end{tabular}

Scale: High $=3.0-4.0$, Moderate $=2.50-2.99$, Low $=1.0-2.49 ;$ and Very low $=0.01-0.99$

Table 2 shows the mean scores and standard deviation on the level of perception of lecturers on what constitutes intellectual property right in universities in Rivers State. The respondents, both Professors and non Professors accepted all the items in the table as intellectual property rights in Universities with mean scores greater than the criterion mean of 2.50. The aggregate mean score of 3.09 with the standard deviation of 0.79 for Professors and 3.05 with standard deviation of 0.42 for non Professors showed that the level of perception of both professors and non Professors is high. Therefore intellectual property right in universities include: Patent, Trademarks, Breeder's right, copyright and Industrial design right. Furthermore, the lecturers rank ordered the intellectual property rights that exist in universities. Copy right was ranked $1^{\text {st }}$, Industrial design right was ranked $2^{\text {nd }}$, Trademark was ranked $3^{\text {rd }}$, Patent was ranked $4^{\text {th }}$, and breeders right was ranked $5^{\text {th }}$.

\subsection{Test of Hypotheses}

The null hypotheses formulated for the study were tested with z-test at 0.05 level of significance. 


\section{Macrothink}

International Journal of Human Resource Studies

ISSN 2162-3058

Ho1: There is no significant difference between the mean perception scores of male and female lecturers on their level of perception of what constitute intellectual property in universities in Rivers State.

Table 3: Comparison between the mean perception score of male and female lecturers on what constitute intellectual property in universities in Rivers State

\begin{tabular}{|l|l|l|l|l|l|l|l|l|}
\hline $\begin{array}{l}\text { Gender of } \\
\text { Lecturers }\end{array}$ & $\mathbf{N}$ & $\bar{X}$ & SD & Df & $\begin{array}{l}\text { Level } \\
\text { of sig. }\end{array}$ & $\begin{array}{l}\text { z-calculated } \\
\text { value }\end{array}$ & $\begin{array}{l}\text { z-critical } \\
\text { value }\end{array}$ & Decision \\
\cline { 1 - 7 } Male & 200 & 3.07 & 0.49 & 344 & 0.05 & 1.52 & \pm 1.96 & $\begin{array}{l}\text { Accept } \\
\mathrm{HO}_{1}\end{array}$ \\
\cline { 1 - 5 } & 146 & 2.98 & 0.58 & & & & \\
\hline
\end{tabular}

The result in table 3 showed the summary of z-test difference between the mean perception score of male and female lecturers on what constitutes intellectual property in universities in Rivers State. The $\mathrm{z}$-calculated value of 1.52 is less than $\mathrm{z}$-critical value of \pm 1.96 at 0.05 level of significance. From the decision rule (z-cal $<\mathrm{z}$-critical), the null hypothesis is accepted. Therefore, there is no significant difference between the mean perception score of male and female lecturers on what constitute intellectual property in universities in Rivers State.

$\mathbf{H O}_{2}$ : There is no significant difference between the mean perception score of Professors and Non Professors on what constitutes intellectual property rights in universities.

Table 4: Comparison between the mean perception score of Professors and Non Professors on what constitutes intellectual property rights in universities

\begin{tabular}{|l|l|l|l|l|l|l|l|l|}
\hline $\begin{array}{l}\text { Status of } \\
\text { Lecturers }\end{array}$ & $\mathbf{N}$ & $\bar{X}$ & SD & Df & $\begin{array}{l}\text { Level of } \\
\text { sig }\end{array}$ & z-cal & z-critical & Decision \\
\hline Professor & 76 & 3.09 & 0.79 & 344 & 0.05 & 0.44 & \pm 1.96 & Accept $\mathrm{HO}_{2}$ \\
\hline $\begin{array}{l}\text { Non } \\
\text { Professor }\end{array}$ & 270 & 3.05 & 0.42 & & & & \\
\hline
\end{tabular}

The result in table 4 showed the summary of z-test difference between the mean perception score of Professors and non Professors on what constitutes intellectual property rights in Universities in Rivers State. The z-calculated value of 0.44 is less than z-critical value of \pm 1.96 at 0.05 level of significance. From the decision rule (z-cal $<$ z-critical), the null hypothesis is accepted. Therefore, there is no significant difference between the mean perception scores of Professors and Non Professors on what constitutes intellectual property rights in universities. 


\section{Discussion of Findings}

The findings of the study reveals that lecturers have a high perception of intellectual property in universities which includes; published prints and electronic books, journals and articles, developed theories, laws, mathematical formula and symbols, scientific research discoveries and inventions, statistical data and reports, paintings and drawing of art. This finding is in line with Branstetter, fisman and Foley (2006) listing of intellectual property. The lecturers' high perception of what constitutes intellectual property is not surprising because it is one of their mandates and creation of adequate number of intellectual property is regarded as high productivity and is used for promotion of lecturers' in universities.

The findings also revealed that the level of perception of lecturers on what constitutes intellectual rights in university is high. The intellectual property right as indicated by the lecturers' includes; Patents, Trademarks, Breeder's right, Copyright and industrial design right. This finding is in line with the university of Port Harcourt intellectual property policy (2013) categorization of intellectual property rights. The findings also agree with that of Maskus and Penubari (1995) which states that intellectual property right include patents, copyright, trademark, labels or plant trader's right. This finding is not surprising because lecturers as a highly educated group of people are aware of their rights both in their profession and in the larger society. The implication of the finding is that; the high perceptions of intellectual property rights makes lecturers desirous of protecting their rights and in turn check the temptation to violate other colleague's property rights. Also lecturers will feel more confident to embark in more creative inventions.

The result emanating from hypothesis 1 showed that there is no significant difference between the perception score of male and female lecturers on what constitutes intellectual property in universities. Also the result of hypothesis 2 reveals that there is no significant difference in the mean perception score of professors and non-professors. This result is not surprising because male and female lecturers, professors and non-professors work in the same environment and do the same type of job, therefore the reason for no significant difference; they perceive what constitutes intellectual property and intellectual property rights in the same way.

\section{Conclusion}

Based on the findings of this study, the researchers concluded that lecturers' perception of intellectual property and intellectual property rights in universities in Rivers State is high. Intellectual property in universities include; Published print and electronic books, journals and articles, Developed theories, laws and mathematical formula and symbols, Scientific research discoveries and inventions, statistical data and reports, printings and drawing of art. Intellectual property rights includes; Patent, Trademark, Breeder's right, Copyright, industrial design right.

Intellectual property and rights is vital for effective and efficient university education delivery because of its influence on economic growth and development of the individuals who produce such inventions and the entire society. 


\section{Recommendations}

Based on the findings of this study, the following recommendations are made;

1. Intellectual property unit should be established and strengthened in all universities for the purpose of screening all intellectual write-ups before publication to ensure quality of intellectual property produced.

2. Special fund should be allocated by Government to universities to enhance the pursuit of efficient and effective management of intellectual property rights in universities.

3. Industries as part of their corporate responsibilities should donate funds to Universities to encourage the procurement of ICT facilities and carry out training to cushion inadequacy of ICT and build capacity in order to enhance the management of intellectual property rights.

4. Research finding should be increased to enable lecturers carry out quality research which will in turn birth more intellectual property.

\section{References}

Africa-Europe faith \& Justice Network, (2002). Equitable protection for intellectual property in Africa. Action plan. Retrieved from aefn@ village.unet.be.http://wvvw.aefjn.org

Branstetter, L.G., Fisman, R. \& Foley, C.F. (2006). Do stronger intellectual property right increase international technology transfer? Em pirical evidence from US Firm-Level Pane Data. Quarterly Journal of Economics. 321-349.

$\begin{array}{lllll}\text { Labour theory of } & \text { Retrieved }\end{array}$ https://en.m.wikipedia.org/wiki/labour_theory_of_labour_property

Maskus, K.E. (1998). The role of intellectual property right in encouraging Foreign direct investment and technology transfer. Duke Journal of Comparative and International Law. 32(47) $1-506$.

Maskus, K.E. \& Penubari, M. (1995). How trade related are intellectual property right? Journal of International Economics. 55(1) 161.

McCalman, P. (2005). International diffusion and intellectual property right:an empirical analysis. Journal of International Economics. 67353-372.

Mendi, P. (2007). Trade in disembodied technology and total factor productivity in organization of economic cooperation and development (OECD), Research Policy, 36, 121-133.

Mendis, D., Seechi, D. \& Reeves, p. (2015). A legal and empirical study into the intellectual property implications of $3 D$ printing. Intellectual property Right office: London.__ $\mathrm{c} \$$

Nagaoka, S. (2005). Determinants of high-royalty contracts and the impact of stronger 


\section{Macrothink}

International Journal of Human Resource Studies

ISSN 2162-3058 2017, Vol. 7, No. 1

protection of intellectual property rights in Japan. Journal of Japanese and International Economics. 19(2) 33-254.

Nicholson, M. (2002). Intellectual property right and internalization: an empirical investigation. Federal Trade Commission, Manuscript.

Peremotode, V.F. (2009). Introduction to educational administration planning and supervision. Lagos: Joja Educational Research and Publishers, Ltd

\section{Copyright Disclaimer}

Copyright for this article is retained by the author(s), with first publication rights granted to the journal.

This is an open-access article distributed under the terms and conditions of the Creative Commons Attribution license (http://creativecommons.org/licenses/by/3.0/). 